\title{
Corticotropin-releasing hormone regulates IL-6 expression during inflammation
}

\author{
Maria Venihaki, ${ }^{1}$ Pieter Dikkes, ${ }^{2}$ Allison Carrigan, ${ }^{1}$ and Katia P. Karalis ${ }^{1}$ \\ ${ }^{1}$ Division of Endocrinology, and \\ ${ }^{2}$ Department of Neurology, Children's Hospital, Harvard Medical School, Boston, Massachusetts, USA \\ Address correspondence to: Katia P. Karalis, Children's Hospital, 300 Longwood Avenue, Boston, Massachusetts 02115, USA. \\ Phone: (617) 355-7302; Fax: (617) 734-0062; E-mail: katia.karalis@tch.harvard.edu.
}

Received for publication April 2, 2001, and accepted in revised form August 27, 2001.

\begin{abstract}
Stimulation of the hypothalamic-pituitary-adrenal (HPA) axis by proinflammatory cytokines results in increased release of glucocorticoid that restrains further development of the inflammatory process. IL-6 has been suggested to stimulate the HPA axis during immune activation independent of the input of hypothalamic corticotropin-releasing hormone (CRH). We used the corticotropin-releasing hormone-deficient $\left(\mathrm{Crh}^{-/-}\right)$mouse to elucidate the effect of CRH deficiency on IL-6 expression and IL-6-induced HPA axis activation during turpentine-induced inflammation. We demonstrate that during inflammation $\mathrm{CRH}$ is required for a normal adrenocorticotropin hormone (ACTH) increase but not for adrenal corticosterone rise. The paradoxical increase of plasma IL- 6 associated with CRH deficiency suggests that IL-6 release during inflammation is CRH-dependent. We also demonstrate that adrenal IL-6 expression is CRH-dependent, as its basal and inflammation-induced expression is blocked by CRH deficiency. Our findings suggest that during inflammation, IL-6 most likely compensates for the effects of CRH deficiency on food intake. Finally, we confirm that the HPA axis response is defective in $\mathrm{Crb}^{-/-} / \mathrm{IL}^{-6^{-/-}}$mice. These findings, along with the regulation of IL- 6 by CRH, support the importance of the interaction between the immune system and the HPA axis in the pathophysiology of inflammatory diseases.
\end{abstract}

J. Clin. Invest. 108:1159-1166 (2001). DOI:10.1172/JCI200112869.

\section{Introduction}

Interaction between the hypothalamic-pituitary-adrenal (HPA) axis, a main coordinator of the stress response, and the immune system during the inflammatory response is supported by a variety of experimental and human studies (1-3). Activation of the HPA axis during immune stimulation is mediated by cytokines and is manifested by increased secretion of adrenocorticotropin hormone (ACTH), which ultimately stimulates synthesis and release of glucocorticoid from the adrenals. Increased glucocorticoid secretion serves to restrain further production of proinflammatory mediators, and thus to prevent propagation of the stress response (4). Corticotropin-releasing hormone (CRH) (5-7) and ACTH (8) are also expressed in peripheral tissues, where they act as proinflammatory factors.

IL-6 is a proinflammatory cytokine whose effects on the HPA axis have been a subject of extended investigation, as its levels are increased during physical, psychological, and inflammatory stress (9-11). The induction of IL- 6 receptor in the paraventricular nucleus during inflammation supports the hypothesis for $\mathrm{CRH}$-mediated stimulation of the HPA axis by IL-6 (12), whereas a recent study concluded that the regulation of the HPA axis by IL- 6 during immune activation is $\mathrm{CRH}$-independent (13). IL-6 administration in rodents induced $\mathrm{ACTH}$ and glucocorticoid secretion (14-16). Prolonged administration of IL-6 in humans led to adrenal enlargement $(17,18)$, and identification of IL- 6 receptors in the adrenal cortex in mice has been postulated to mediate direct stimulatory effects of IL-6 on glucocorticoid release in this species (13). These findings led to the hypothesis (17, 19) that IL-6 might be the "tissue CRF," a circulating factor identified almost half a century ago by its delayed (compared with central CRH) but prolonged stimulatory effect on HPA axis (20).

$\mathrm{Crh}^{-1-}$ mice have normal basal ACTH levels although they fail to mount the expected ACTH and glucocorticoid response after physiological or psychological stimuli $(21,22)$, indicating that $\mathrm{CRH}$ is necessary for the activation of the pituitary-adrenal axis by these stressors. However, we have shown significant, although not as much as in the wild-type $\left(\mathrm{Cr}^{+/+}\right)$mice, elevation of corticosterone in $\mathrm{Crh}^{-/-}$mice during carrageenininduced acute inflammation (23). Furthermore, in a recent report, normal HPA axis activation after stimulation of the immune system by administration of 2C11 was found in the $\mathrm{Crb}^{-/-}$mice, as shown by their plasma ACTH and corticosterone levels (13). These data led to the conclusion that $\mathrm{CRH}$ is not required for a normal HPA axis activation in this condition, in support of the older studies on the nonhypothalamic humoral substance that can directly stimulate the secretion of ACTH $(20,24)$. 
Turpentine-induced hind limb abscess, a well-established model of subacute inflammation in rodents (25), is associated with very high levels of circulating IL-6, prolonged activation of the HPA axis (26) and metabolic alterations such as anorexia and weight loss $(27,28)$. Studies in rats have suggested hypothalamic CRH as the mediator of the activation of the HPA axis during turpentine-induced inflammation, as administration of a $\mathrm{CRH}$ antagonist blocked the pituitary-adrenal response in inflamed animals (26). In contrast, when the turpentine model of inflammation was applied to $\mathrm{CRH}$ receptor 1-deficient $\left(\mathrm{Crhr}^{-/}\right)$mice, plasma ACTH and corticosterone levels were found similarly elevated to those of their wild-type littermates, with IL-6 levels significantly higher (two- to threefold) in the former (29). This study suggested that during inflammation, in the absence of the CRH effect on the pituitary $\mathrm{CRH}$ receptor 1 (CRHR1), IL-6 stimulates pituitary ACTH secretion, resulting in a normal HPA activation.

In our study we applied the turpentine model of inflammation to the $\mathrm{Crh}^{-/-}$mouse to elucidate the role of $\mathrm{CRH}$ on the regulation of IL- 6 expression and the activation of the pituitary-adrenal axis during inflammation.

\section{Methods}

Animal housing. $\mathrm{Crb}^{+/+}, \mathrm{Crb}^{-/-}, \mathrm{Il6}^{-/-}$, and $\mathrm{Crb}^{-/-} / \mathrm{Il6}^{-/-}$mice of $129 \times \mathrm{C} 57 \mathrm{BL} / 6$ genetic background were housed with ad libitum access to rodent chow on a 12 hour light/dark cycle (lights on at 7:00 am). Animal housing and care was done according to NIH guidelines, and all experiments were approved by the Animal Care and Use Committee of Children's Hospital in Boston. All experiments were performed in mice of 2-4 months of age. Animals were housed individually at least 48 hours before each experiment. For the experiments involving daily monitoring of body weight and food intake, mice and their administered food were weighed before turpentine injection (see below) and every 24 hours for a total of 5 days after injection.

Adrenalectomy. Adrenalectomy and sham adrenalectomy were performed via the retroperitoneal route under avertin (2.5\%) anesthesia, as described previously (23). Pellets (40 mg; 25\% wt/wt corticosterone/cholesterol) were made as described previously (23) and implanted subcutaneously in the adrenalectomized mice at the time of adrenalectomy to provide constant amount of circulating levels of corticosterone. Adrenalectomized mice were given $0.9 \%$ normal saline as drinking water and were left to recover for at least 6 days before any experimental procedure. Successful adrenalectomy was confirmed by evaluation of plasma corticosterone levels. Induction of local inflammation and blood collection. Local inflammation was induced by intramuscular injection of $100 \mu \mathrm{l}$ of turpentine oil into the right hind limb under avertin anesthesia. Control animals received a similar injection of $100 \mu \mathrm{l}$ of sterile normal saline. Blood samples for hormone and cytokine levels were collected by retroorbital eye bleeding of conscious mice (four to five mice per group). Thus, a separate group of turpentine- or saline-injected mice was bled for each time point studied, i.e., 1, 4, 8, 16, 24, 36, or 48 hours, as indicated in the figure legends. Blood collection was timed so that it always occurred at the same circadian time; namely, 1 one hour after lights had been turned on. After blood collection, mice were sacrificed by decapitation, and the pituitaries and adrenals were dissected aseptically and immediately frozen on dry ice. ACTH immunoneutralization. For the experiments involving immunoneutralization of ACTH, $0.5 \mathrm{ml}$ of ACTH antibody (titer 1:32,276; kindly provided by G.P. Chrousos, National Institute of Child Health and Human Development, Bethesda, Maryland, USA) was administered intraperitoneally 1 hour before and 5 hours after the injection of turpentine or saline to both $\mathrm{Crb}^{+/+}$and $\mathrm{Crb}^{-/-}$mice. In a separate experiment, $1 \mathrm{ml}$ of the same antibody was administered twice to $\mathrm{Crb}^{+/+}$mice only.

Tissue preparation. After avertin anesthesia, mice were transcardially perfused with $4 \%$ paraformaldehyde in PBS 16 hours after the injection of turpentine or saline. Injected muscles were removed, post-fixed in $4 \%$ paraformaldehyde in PBS for 24 hours, dehydrated in increasing concentrations of ethanol followed by xylene, and embedded in paraffin. Sections $(5 \mu \mathrm{M})$ cut in a rotary microtome (Reichert-Jung, Allendale, New Jersey, USA) were stained with hematoxylin and eosin (H\&E) staining. Qualitative evaluation of tissue histology was performed independently by two investigators.

\section{Semiquantitative RT-PCR}

Total RNA preparation and RT-PCR. RNA from pituitary, adrenal, muscle, and liver from both $\mathrm{Crb}^{+/+}$and $\mathrm{Crb}^{-/-}$ mice was prepared using TRI reagent (Sigma Chemical Co., St. Louis, Missouri, USA). The quantity of RNA was estimated by spectrophotometry. Two micrograms of total RNA were used for cDNA synthesis initiated from random hexamer primers (Life Technologies Inc., Rockville, Maryland, USA) as we have described previously $(30,31)$.

Mouse specific primers for the IL-6 (32) and $\beta$-actin (33) mRNAs were commercially obtained (Biosource International, Camarillo, California, USA). The sequence of the sense and antisense primers follows: Primers: size of product (bp); $\beta$-actin sense $5^{\prime}$-TCAGAAGGACTCCTATGTGG-3' 500; $\beta$-actin antisense $5^{\prime}$ TCTCTTTGATGTCACGCACG-3'; IL- 6 sense $5^{\prime}$-TGGAGTCACAGAAGGAGTGGCTAAG-3'155; IL-6 antisense 5'-TCTGACCACAGTGAGGAATGTCCAC-3'.

Amplification of the cDNA was done using the following conditions: $94^{\circ} \mathrm{C}$ for 3 minutes for denaturation, following by 25 cycles of denaturation (at $94^{\circ} \mathrm{C}$ ) for 1 minute, annealing at $55^{\circ} \mathrm{C}$ or $62^{\circ} \mathrm{C}$ for $\beta$-actin or IL-6, respectively for 1 minute, and extension at $72^{\circ} \mathrm{C}$ for 2 minutes. Reactions were completed with an additional 3-minute extension at $72^{\circ} \mathrm{C}$. PCR reactions were performed in a $100-\mathrm{ml}$ volume containing $1 \mathrm{x}$ PCR buffer, deoxynucleotides (Roche Molecular Biochemicals, Indianapolis, Indiana, USA) at a final concentra- 
tion of $0.2 \mathrm{nM}$ each, $30 \mathrm{pmol}$ of the specific primers, and Taq DNA polymerase (PGC Scientifics, Gaithersburg, Maryland, USA). PCR products were analyzed by electrophoresis through $1.5 \%$ agarose gels.

Plasma hormone and cytokine assays. Blood samples were centrifuged at $1,925 \mathrm{~g}$ at $4^{\circ} \mathrm{C}$ for 10 minutes, and plasma was separated, aliquoted, and stored at $-80^{\circ} \mathrm{C}$ until further use. Plasma ACTH (Incstar, Stillwater, Minnesota, USA) and corticosterone (ICN Radiochemicals Inc., Orangeburg, New York, USA) levels were measured using commercial RIA kits. Plasma IL- 6 concentrations were measured by commercial ELISA kit (R\&D Systems Inc., Minneapolis, Minnesota, USA).

Statistical analysis. In all experiments, each group consisted of three to six mice, and each individual experiment was performed at least twice. Data were analyzed by ANOVA, followed by Scheffe's and Fisher's least significant difference post hoc multiple comparison tests. For the experiments recording body weight and food intake, the analysis was performed by nonparametric tests. For all analyses, $P<0.05$ was considered significant. In the figures where standard error bars are not visible, they are smaller than the resolution of the symbols.

\section{Results}

Time course of the response to turpentine

Hormonal and cytokine responses. The time course of the pituitary-adrenal response to turpentine administration of $\mathrm{Cr}^{+/+}$and $\mathrm{Crh}^{-/-}$mice was evaluated by measurement of plasma ACTH and corticosterone levels at $1,4,8,16,24,30$, and 48 hours after the injection (Figure 1 , $a$ and $b$ ). One hour afterward, either saline- or turpentine-injection corticosterone was significantly elevated in $\mathrm{Crb}^{+/}$but not in $\mathrm{Crb}^{-/-}$mice (Figure 1b). This rise has most likely resulted from the pain of the injection, a stressor previously shown to cause no activation of the pituitary-adrenal responses in $\mathrm{Crb}^{-/-}$mice (34). Furthermore, lack of any significant rise in TNF- $\alpha$, IL-1 $\beta$, and IL- 6 at the same time point (data not shown), suggests that this corticosterone rise is unlikely to result from activation of the immune system. No significant changes from the baseline values were revealed in the corticosterone levels of either genotype 4-48 hours after saline administration. Up to 4 hours after the turpentine administration, corticosterone levels in $\mathrm{Crb}^{+++}$mice were higher than those of the $\mathrm{Crb}^{-/-}$ mice (Figure 1b), suggesting the possibility of an earlier activation of the pituitary-adrenal axis in the former.

\footnotetext{
Figure 1

Time course of ACTH, corticosterone, and IL- 6 responses to turpentine. Plasma ACTH (a), corticosterone (b), and IL-6 (c) levels in male $\mathrm{Crh}^{+/+}$and in $\mathrm{Crh}^{-/-}$mice 1-48 hours after saline or turpentine injection. Values represent mean \pm SEM. ${ }^{*}$ Statistical difference $(P<0.05)$ between saline- and turpentine-injected mice of the same genotype. "Statistical difference $(P<0.05)$ between $\mathrm{Crh}^{+/+}$and $\mathrm{Crh}^{-/-}$ mice subjected to the same treatment $(n=4-5$ animals per group per experiment).
}

Levels of both ACTH and corticosterone in $\mathrm{Cr}^{+/+}$mice peaked between 8 and 16 hours (Figure 1, a and b) and remained significantly elevated for 24-30 hours after the turpentine injection. In the $\mathrm{Crb}^{-/-}$mice, the rise of ACTH was not statistically significant at any time point studied (Figure 1a), despite their marked corticosterone increase, similar to that of the $\mathrm{Crb}^{+/+}$mice, from 8 up to 30 hours after the injection of turpentine (Figure 1b). To confirm that this finding was not due to the small number $(n=4$ animals per experimental group per genotype) of animals included in an individual experiment, we also analyzed the data from several experiments pooled together, which also did not reveal any statistically significant difference at ACTH levels at any of the time points studied (data not shown).
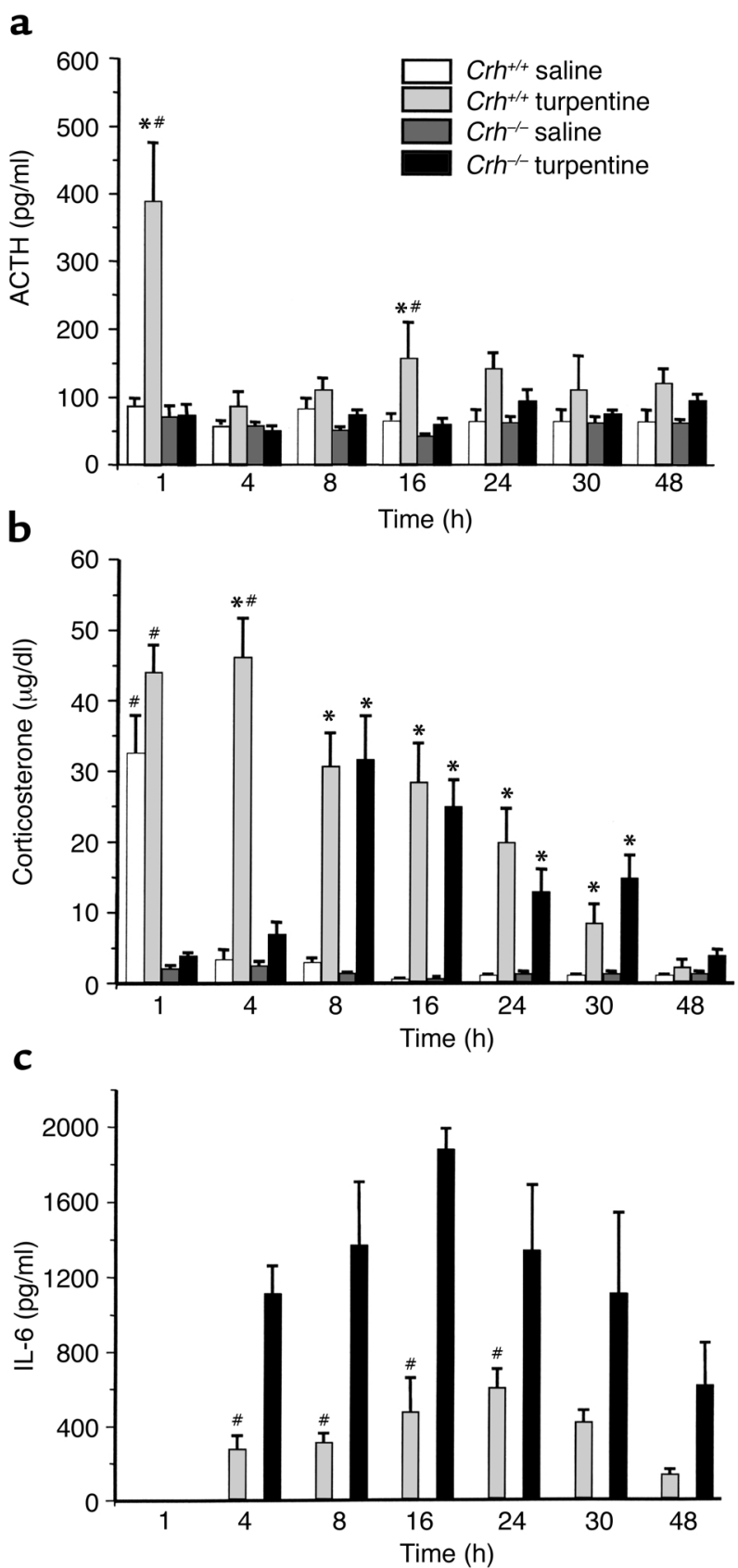


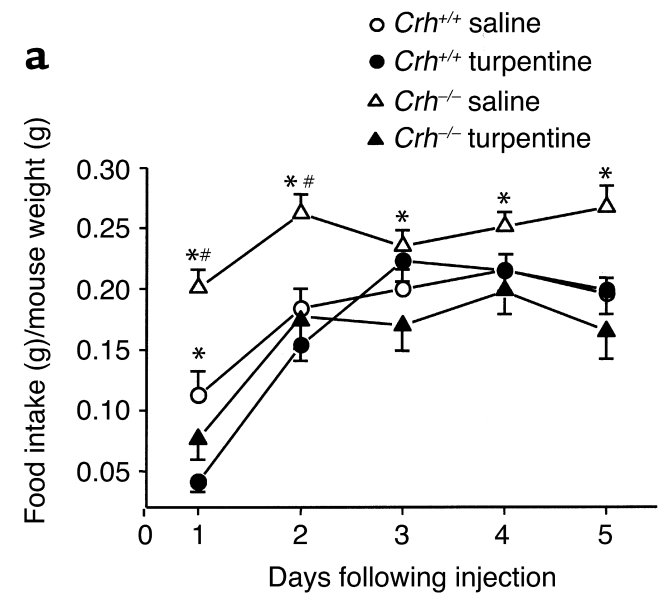

b

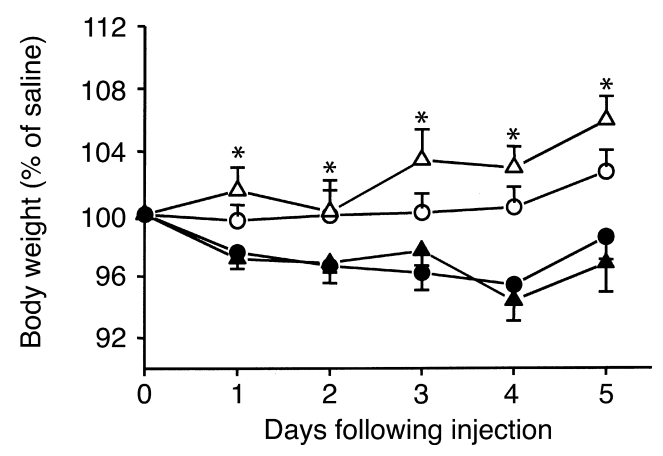

Plasma IL-6 levels, measured in parallel to ACTH and corticosterone, were markedly increased in both $\mathrm{Cr}^{+/+}$ and $\mathrm{Crb}^{-/-}$mice 4 hours after the injection, peaked at 16 hours, and remained elevated for 30 hours after the injection (Figure 1c). In $\mathrm{Crb}^{-/-}$mice, IL-6 levels were two- to threefold those of the $\mathrm{Cr}^{+/+}$mice, whereas saline-injected mice of both genotypes had IL-6 levels below the detection limit $(15.6 \mathrm{pg} / \mathrm{ml})$ of our assay.

Metabolic response. Body weight and food consumption of turpentine- or saline-injected $\mathrm{Cr}^{+/+}$and $\mathrm{Crb}^{-/-}$ mice were monitored for 5 days after the injection. As shown (Figure 2a) 24 hours after the turpentine injection food intake, expressed as food intake/body weight, was decreased to a similar degree in both $\mathrm{Crb}^{+/+}$and $\mathrm{Crh}^{-1-}$ mice and had returned to the baseline level in both groups 72 hours after injection. In parallel, body weight reduced to the same percent in both genotypes starting as soon as the second day after the injection (Figure 2b). Saline-injected $\mathrm{Cr}^{+/+}$maintained their

\footnotetext{
Figure 3

Histological evaluation of inflamed tissues. Representative sections of saline- and turpentine-injected hind limbs stained with $\mathrm{H} \& \mathrm{E}$ from $\mathrm{Crh}^{+/+}$and $\mathrm{Crh}^{-/-}$mice injected with $100 \mu \mathrm{l}$ of either saline (a and $\mathbf{c}$ ) or turpentine (b and $\mathbf{d}), 16$ hours after the injection. No differences were detected between $\mathrm{Crh}^{+/+}$and $\mathrm{Crh}^{-/-}$saline-injected mice (a and c, respectively). However, $\mathrm{Crh}^{+/+}$turpentine-injected mice had higher inflammatory response than did $\mathrm{Crh}^{-/-}$mice (b and $\mathbf{d}$, respectively), as shown by the leukocyte infiltration.
}

\section{Figure 2}

Food intake and body weight change after turpentine injection. Food (a) and body weight (b) monitored every morning for 5 days in male $\mathrm{Crh}^{+/+}$(circles) and $\mathrm{Crh}^{-/-}$(triangles) mice injected on day 1 with either saline (open symbols) or turpentine (filled symbols). Values represent mean \pm SEM. ${ }^{*}$ Statistical difference $(P<0.05)$ between saline- and turpentine-injected mice of the same genotype. "Statistical difference $(P<0.05)$ between $\mathrm{Crh}^{+/+}$and $\mathrm{Crh}^{-/-}$mice subjected to the same treatment ( $n=4-9$ animals per group per experiment). (a) Significant differences were found in food intake between the $\mathrm{Crh}^{+/+}$turpentineinjected and $\mathrm{Crh}^{+/+}$saline-injected groups on day 1 and at all time points studied between $\mathrm{Crh}^{-/-}$turpentine-injected and $\mathrm{Crh}^{-/-}$salineinjected mice. No differences were detected in food intake between turpentine-injected $\mathrm{Crh}^{+/+}$and $\mathrm{Crh}^{-/-}$groups. (b) No differences were detected in body weight changes between $\mathrm{Crh}^{+/+}$and $\mathrm{Crh}^{-/-}$groups after either saline or turpentine injection. Body weight was significantly lower at days 3-5 in both $\mathrm{Crh}^{+/+}$and $\mathrm{Crh}^{-/-}$turpentine-injected, compared with the $\mathrm{Crh}^{+/+}$and $\mathrm{Crh}^{-/-}$saline-injected, groups.

body weight, although their food intake was reduced for 1 day after the injection. Interestingly, we found no change in food intake of the $\mathrm{Crb}^{-/-}$saline-injected mice.

Limb histology. Histological evaluation of the inflamed areas from both genotypes was performed 16 hours after the induction of inflammation, a time point previously shown to coincide with the peak of the local response (25). Turpentine-injected $\mathrm{Crb}^{+/+}$and $\mathrm{Crh}^{-/-}$mice raised a significant inflammatory response (Figure $3, \mathrm{~b}$ and $\mathrm{d}$, respectively) compared with their saline-injected respective controls (Figure 3, a and c). The inflammatory response of the $\mathrm{Crb}^{+/+}$was significantly higher than that of the $\mathrm{Crb}^{-/-}$mice as judged by the leukocytic infiltration of the inflamed area (Figure 3, b and d, respectively).

Response to turpentine after adrenalectomy. We next evaluated the ACTH and IL- 6 response to turpentine injection of $\mathrm{Crb}^{+/+}$and $\mathrm{Crb}^{-/-}$mice that had their corticosterone clamped to the same level by adrenalectomy. Thus, turpentine- or saline-injected $\mathrm{Crb}^{+/+}$and $\mathrm{Crb}^{-/-}$ sham-adrenalectomized (sham), adrenalectomized $(\mathrm{adx})$, or adrenalectomized and replaced with corticosterone $(\mathrm{adx} / \mathrm{cort})$ mice were studied 16 hours after the injection, a time point previously shown to correspond to the peak of the HPA axis and cytokine response (26). $\mathrm{Crb}^{+/+} / \mathrm{adx}$ mice had very high basal ACTH levels (data not shown), as expected by the loss of the negative feed-

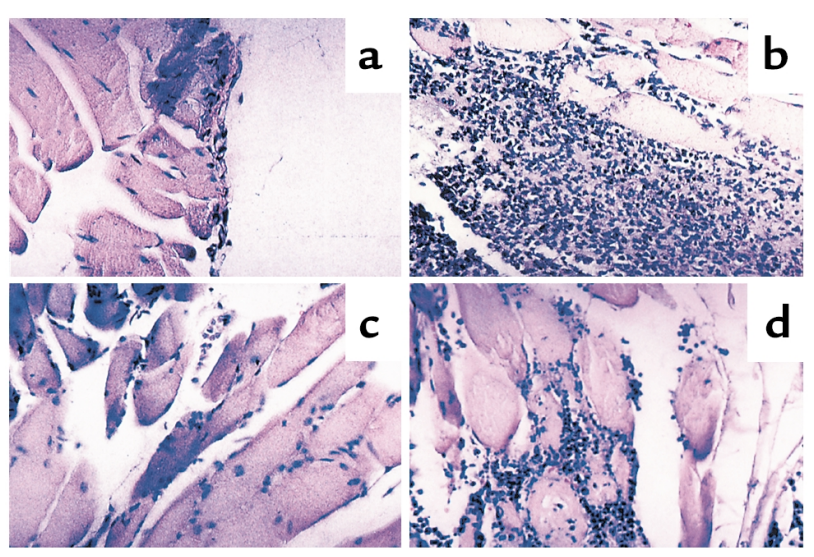




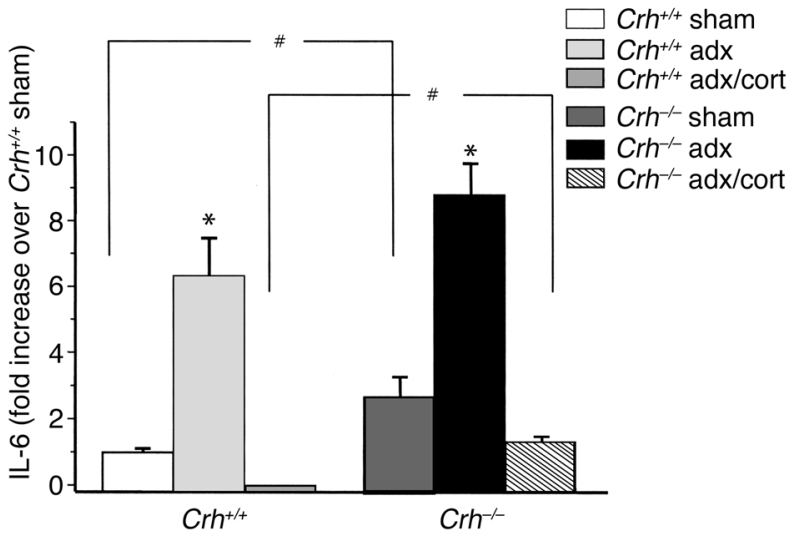

\section{Figure 4}

IL-6 responses to turpentine injection in adrenalectomized mice. Plasma IL-6 levels in male $\mathrm{Crh}^{+/+}$and $\mathrm{Crh}^{-/-}$mice, sham-adrenalectomized mice (sham), mice adrenalectomized with corticosterone replacement ( $\mathrm{adx} / \mathrm{cort})$, and adrenalectomized with no corticosterone replacement $(\mathrm{adx}) 16$ hours after turpentine injection. Values represent fold increase over saline-injected $\mathrm{Crh}^{+/+}$mice. ${ }^{*}$ Statistical difference $(P<0.05)$ between saline- and turpentine-injected mice of the same genotype. "Statistical difference $(P<0.05)$ between $\mathrm{Crh}^{+/+}$and $\mathrm{Crh}^{-/-}$mice subjected to the same treatment $(n=4-5$ animals per group per experiment).

back effect of glucocorticoid, whereas no change in the basal ACTH levels was detected between the sham and adx $\mathrm{Crb}^{-/-}$groups, as has been reported previously (34) (data not shown). Plasma levels of IL-6 were significantly and to the same extent elevated in both the $\mathrm{Crb}^{+/+}$ and $\mathrm{Crb}^{-/-}$adx compared with the sham groups, as expected after the loss of the inhibitory effect of glucocorticoid (Figure 4). Interestingly, plasma IL-6 levels were significantly elevated in the $\mathrm{Crb}^{-/-}$adx/cort although undetectable in the $\mathrm{Cr}^{+/+}$adx/cort mice (Figure 4), despite their similar corticosterone levels $\left(\mathrm{Cr}^{+/+}\right.$ $9.3 \pm 2.1 \mu \mathrm{g} / \mathrm{dl}$ and $\mathrm{Crb}^{-/-} 7.8 \pm 1 \mu \mathrm{g} / \mathrm{dl}$ ).

Response to turpentine after immunoneutralization of ACTH. Plasma corticosterone and IL-6 levels were evaluated in saline- and turpentine-injected $\mathrm{Cr}^{+/+}$and $\mathrm{Crb}^{-/}$mice treated with an ACTH antibody as described in Methods. Cotreatment with the ACTH antibody did not block the corticosterone rise of the turpentine-injected $\mathrm{Crb}^{+/+}$mice $\left(\mathrm{Cr}^{+/+}\right.$turpentineinjected versus $\mathrm{Crb}^{+/+}$turpentine-injected/ACTH antibody administered mice: $47.7 \pm 8.5 \mathrm{vs.} 42.9 \pm 2.5 \mu \mathrm{g} / \mathrm{dl}$ ), and it abolished the corticosterone response of the $\mathrm{Crb}^{-/-}$mice ( $\mathrm{Crb}^{-/-}$turpentine-injected versus $\mathrm{Crb}^{-/-}$turpentine-injected/ACTH antibody administered mice: $38.2 \pm 4.2$ vs. $13 \pm 10 \mu \mathrm{g} / \mathrm{dl}$ ). Furthermore, administration of ACTH antibody to $\mathrm{Crb}^{+/+}$mice at twice the previous dose in a separate experiment did not reveal any effect on the corticosterone rise after turpentineinduced inflammation ( $\mathrm{Crb}^{+/+}$turpentine-injected versus $\mathrm{Cr}^{+/+}$turpentine-injected/ACTH antibody administered mice: $32.6 \pm 9.2$ versus $53.4 \pm 11.2 \mu \mathrm{g} / \mathrm{dl}$ ). A significant elevation of the plasma IL-6 levels was found in the $\mathrm{Crb}^{-/-}$mice administered the ACTH anti- body ( $\mathrm{Crb}^{-/-}$turpentine-injected versus $\mathrm{Crh}^{-/-}$turpentine-injected/ACTH antibody administered mice: $1,285 \pm 319$ vs. $8,877 \pm 922 \mu \mathrm{g} / \mathrm{dl}$ ), although, to our surprise, in the $\mathrm{Cr}^{+/+}$mice immunoneutralization of ACTH led to a significant reduction of the rise in IL- 6 $\left(\mathrm{Crb}^{+/+}\right.$turpentine-injected versus $\mathrm{Crb}^{+/+}$turpentineinjected/ACTH antibody administered mice: $736 \pm 128$ vs. $284 \pm 43 \mu \mathrm{g} / \mathrm{dl})$. These findings suggest that in the $\mathrm{Crb}^{+/+}$mice, either the amount of the ACTH antibody administered was not enough to block the effect of the very high levels of ACTH on the adrenal, or in the presence of CRH there are factors additional to ACTH that may act as adrenal secretagogues. It is interesting that the release of corticosterone was abolished in the $\mathrm{Crh}^{-/-}$ mice after the immunoneutralization of $\mathrm{ACTH}$, despite the concomitant very high circulating IL-6 levels. These results suggest that the regulation of both the release of corticosterone and the secretion of IL- 6 is different in states of CRH deficiency.

Hormonal response to turpentine in $\mathrm{Crb}^{-1-} / \mathrm{Il6}^{-/-}$mice. Plasma ACTH and corticosterone levels were evaluated in $\mathrm{Il6}^{-/-}$and $\mathrm{Crb}^{-/-} / \mathrm{Il6}^{-/-}$mice 16 hours after turpentine injection and the results were compared with those obtained from $\mathrm{Crb}^{+/+}$and $\mathrm{Crb}^{-/-}$mice at the same time point. As shown in Table 1, basal ACTH and corticosterone levels did not differ between the four genotypes. However, after turpentine injection, plasma ACTH levels were significantly elevated in both $\mathrm{Cr}^{+/+}$and $\mathrm{Il}^{-/-}$ mice, whereas $\mathrm{Crb}^{-/-}$and $\mathrm{Crb}^{-1-} / \mathrm{Il6}^{-/-}$mice failed to mount any significant response. Plasma corticosterone levels were significantly elevated in $\mathrm{Cr}^{+/+}, \mathrm{Crb}^{-/-}$, and $\mathrm{Il}^{-/-}$mice, whereas those of the $\mathrm{Crb}-/ / \mathrm{Il}^{-/-}$did not differ from the basal values.

Tissue IL-6 expression in $\mathrm{Crb}^{+/+}$and $\mathrm{Crb}^{-/-}$mice. IL-6 mRNA expression was analyzed by RT-PCR in pituitary, adrenal, liver, and muscle obtained from saline- or turpentine-injected $\mathrm{Crb}^{+/+}$and $\mathrm{Crh}^{-/-}$mice. We were unable to detect any IL-6 expression in the pituitary of either saline- or turpentine-injected mice of either genotype (data not shown). IL-6 mRNA was detected in the adrenal of both saline- and turpentine-injected $\mathrm{Cr} b^{+/+}$mice

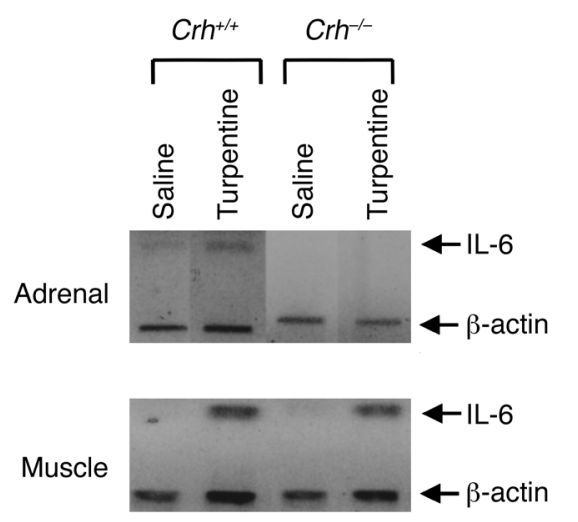

Figure 5

Tissue IL-6 expression after turpentine injection. Total RNA from adrenal and muscle from saline- or turpentine-injected $\mathrm{Crh}^{+/+}$and $\mathrm{Crh}^{-/-}$ mice was subjected to RT-PCR for evaluation of IL- 6 expression. 
Plasma ACTH and corticosterone levels in female $\mathrm{Crh}^{+/+}, \mathrm{Crh}^{-/-}, 116^{-/-}$, and $\mathrm{Crh}^{-/-} / 116^{-/-}$mice under basal state and following turpentine injection

\begin{tabular}{llccc}
\hline & \multicolumn{2}{c}{ ACTH $(\mathrm{pg} / \mathrm{ml})$} & \multicolumn{2}{c}{ Corticosterone $(\mu \mathrm{g} / \mathrm{dl})$} \\
$\mathrm{Crh}^{+/+}$ & Basal & Turpentine & Basal & Turpentine \\
$\mathrm{Crh}^{-/-}$ & $48 \pm 2.9$ & $324 \pm 134^{\mathrm{A}, \mathrm{B}}$ & $2.4 \pm 0.4$ & $36 \pm 13^{\mathrm{A}, \mathrm{B}}$ \\
$I / 6^{-/-}$ & $56 \pm 2.3$ & $88 \pm 8.3^{\mathrm{B}}$ & $1.9 \pm 0.3$ & $23 \pm 5$ \\
$\mathrm{Cr} h^{-/} / I 16^{-/-}$ & $62 \pm 11.7$ & $131 \pm 40^{\mathrm{B}}$ & $1.8 \pm 0.2$ & $15 \pm 2.6$ \\
\hline
\end{tabular}

AStatistical difference $(P<0.05)$ between saline- and turpentine-injected mice of the same genotype. ${ }^{B}$ Statistical difference $(P<0.05)$ between mice of the different genotypes subjected to the same treatment $(n=3-4$ animals per group per experiment).

with significantly increased levels in the latter (Figure 5). Interestingly, no band was detected in $\mathrm{Crb}^{-/-}$mice after either treatment (Figure 5), even when the cDNA was subjected to further amplification (up to 45 cycles). IL-6 mRNA abundance was similar in the liver of mice of either genotype after saline- or turpentine injection (data not shown). This suggests that either liver IL-6 is not altered during inflammation, or that 16 hours after the induction of inflammation is well beyond the time of IL-6 induction in this tissue. Finally, IL- 6 mRNA expression was assessed in the muscle of turpentine-or saline-injected muscles. Noninflamed muscles from either genotype did not show any significant expression, although similar abundance of IL- 6 was detected in the inflamed tissues from both genotypes (Figure 5). Given that the infiltrating leukocytes, most likely the cellular source of IL-6, are significantly less in the inflamed muscle of the $\mathrm{Crb}^{-/}$(Figure 3), it is possible that IL-6 expression is elevated in this tissue in the $\mathrm{Crb}^{-/-}$mice.

\section{Discussion}

We demonstrate here that the expression of IL-6 during inflammation is regulated by CRH in a tissue-specific manner. We also show that $\mathrm{CRH}$ is necessary for the induction of a normal rise of plasma ACTH during inflammation. We found that inflammation induced a similar rise in corticosterone in both $\mathrm{Crb}^{+/+}$ and $\mathrm{Crb}^{-/-}$mice (Figure 1b), although we did not detect a statistically significant change in plasma ACTH levels in the $\mathrm{Crb}^{-/-}$mice at any time point after turpentine injection (Figure 1a).

In previous studies, $\mathrm{Cr}^{-/-}$mice failed to mount a normal HPA response to a variety of psychological and/or physical stressors $(21,22,35,36)$. We and others have shown that immune stimuli induce an HPA response in the $\mathrm{Crb}^{-/-}$mice, although not always to levels similar to those of the $\mathrm{Crb}^{+/+}$mice (refs. 13, 23; and M. Venihaki and K.P. Karalis, unpublished observations). In a recent report, it was shown that after administration of 2C11, an immune system activator, $\mathrm{Crb}^{-/-}$mice elicited a normal adrenal response in the presence of ACTH levels significantly higher from those of the $\mathrm{Cr} b^{+/+}$mice (13). This effect was attributed to their significantly elevated IL-6 levels, as intraperitoneal administration of IL- 6 elicited a similar paradoxical ACTH release in the $\mathrm{Crh}^{-/-}$mice. Our findings during turpentine inflammation demon- strate similar to the $\mathrm{Crb}^{+/+}$mice corticosterone rise in the $\mathrm{Crb}^{-/-}$mice despite their significantly compromised ACTH response. Although we have selected the timing for sampling in order to include the ACTH and corticosterone peaks and nadirs (26), we cannot exclude the possibility that we missed a significant rise in ACTH in the $\mathrm{Crb}^{-/-}$mice. We cannot also exclude the possibility that the rise in ACTH in $\mathrm{Crb}^{-/-}$mice is so small that it may be lost in the scatter of the ACTH RIA. However, even such a small rise might explain the normal corticosterone response of the $\mathrm{Crb}^{-/-}$mice as well as the blockade of this response by administration of the ACTH antibody (Figure 1b, and Results).

IL-6 levels in $\mathrm{Crh}^{-/-}$inflamed mice were two to three times higher compared with those of the $\mathrm{Cr}^{+/+}$mice (Figure 1c and Figure 4), in agreement with reports using other models of immune activation (13). The very high levels of IL-6 in the $\mathrm{Crh}^{-/-}$mice despite their normal corticosterone rise, in addition to the further elevation of IL- 6 after immunoneutralization of ACTH, suggest that the regulation of IL- 6 secretion during inflammation is not CRH-independent. The above hypothesis is also suggested by the differences in the IL-6 levels between $\mathrm{Crb}^{-/-}$and $\mathrm{Crb}^{+/+}$mice (Figure 1c). In the former, immunoneutralization of ACTH blocked the corticosterone rise and resulted in the expected further increase. In the latter, although the administered dose of the ACTH antibody did not result to a detectable fall in plasma corticosterone levels, there was a significant reduction of the IL-6 levels that might reflect the corresponding changes in central and peripheral CRH expression. These findings, in addition to the flat HPA axis response of mice with CRH and IL-6 deficiencies $\left(\mathrm{Crb}^{-/-} / \mathrm{Il}^{-/-}\right)$(Table 1$)$ and findings from studies on IL-6-deficient mice (Il6-/-) (37), suggest that IL-6 is not a CRH-independent regulator of the HPA axis during inflammation unlike in other states of immune system activation (13), and even that after this stressor CRH and IL-6 may act in parallel to stimulate glucocorticoid secretion.

$\mathrm{Crb}^{-/-}$mice had a significantly lower inflammatory reaction compared with the $\mathrm{Crb}^{+/+}$mice, as judged by tissue leukocytic infiltration (Figure 3). As we have shown previously, immunoneutralization of peripheral CRH significantly inhibited the carrageenin-induced granuloma in rats (5). Similar findings were reported 
recently by others and us after administration of a $\mathrm{CRH}$ antagonist to inflamed rats (38) or mice (23). We believe that the reduced inflammatory response of the $\mathrm{Crb}^{-/-}$mice after turpentine administration is most likely due to their CRH deficiency and thus, lack of the peripherally expressed proinflammatory $\mathrm{CRH}$. The contribution of peripheral CRH deficiency on the stimulation of pituitary ACTH by cytokines, shown previously to be preserved in immune-challenged rats administered Escherichia coli following removal of the medial hypothalamus $(39,40)$, needs further study.

In our previous studies, we have applied the model of carrageenin-induced acute inflammation and found that $\mathrm{Crb}^{-1-}$ mice exhibited a mild corticosterone increase compared with the $\mathrm{Cr}^{+/+}$mice and a markedly diminished inflammatory response only after adrenalectomy (23). The carrageenin-induced inflammatory response is mediated to a great extent by histamine and kinins (41), whereas the turpentine-induced inflammation is mainly mediated by increased cytokine release (25). The differences between the responses induced as just described might represent the variations in the peak of the inflammatory response and the nature of the proinflammatory mediators involved in each of these models.

CRH and IL- 6 are potent anorexigenic factors for humans and rodents (42-46). The resistance of $\mathrm{Il6}^{-/-}$ mice to turpentine-induced weight loss and anorexia (37) further demonstrates the critical role of IL-6 in these processes. Thus, the significant abundance of circulating IL-6 in the turpentine-injected $\mathrm{Crh}^{-/-}$mice may account for the similar changes in body weight and food intake in the two genotypes (Figure 2) (47). To our surprise, food intake was normal in the saline-injected $\mathrm{Crh}^{-/-}$mice, although diminished in the saline-injected $\mathrm{Crb}^{+/+}$mice (Figure 2, a and b). This is to our knowledge the first study demonstrating a difference in food intake and parallel body weight change between $\mathrm{Cr}^{+/+}$and $\mathrm{Crb}^{-/-}$mice. It is possible that saline injection, as a mild stressor, unmasked differences in food intake between $\mathrm{Crb}^{+/+}$and $\mathrm{Crb}^{-/-}$mice resulting from the anorexigenic properties of $\mathrm{CRH}$ alone, while more severe stress paradigms alter the expression of various hypothalamic factors involved in the regulation of food intake (48).

The tissue(s) of origin of the high IL-6 levels during inflammation in either $\mathrm{Crb}^{+/+}$or $\mathrm{Cr}^{-/-}$mice has not been conclusively identified by our studies. The high levels of IL-6 in adrenalectomized $\mathrm{Crb}^{+/+}$and $\mathrm{Crb}^{-/-}$ mice (Figure 4) suggest that the adrenal gland is not the main source of circulating IL-6 during inflammation. Increased expression of IL- 6 in the adrenal of $\mathrm{Crb}^{+/+}$mice during inflammation (Figure 5) suggests that adrenal IL-6 may participate in the inflammatory process. Interestingly, IL- 6 expression was undetectable in the adrenal of $\mathrm{Crb}^{-/-}$mice in basal state (Figure 5), although inflammation did not induce its expression, in contrast to the $\mathrm{Cr}^{+/+}$mice, suggesting that $\mathrm{CRH}$, most likely of peripheral origin, is a major regulator of adrenal IL- 6 . The possibility that the infiltrating leukocytes in the inflamed tissue might be the source of the higher IL-6 expression in $\mathrm{Crh}^{-/-}$ mice, as discussed above, needs to be further addressed by in vitro studies.

In summary, we have shown that $\mathrm{CRH}$ deficiency is related to paradoxically increased plasma levels of IL- 6 that may act as a CRH-dependent regulator of ACTH secretion but not of glucocorticoid release. We also demonstrate a novel role for $\mathrm{CRH}$ as a major regulator of adrenal IL-6, which further supports the possibility of IL- 6 being the previously identified "tissue CRF" (20, 24). The significance of the tissue-specific regulation of IL- 6 by CRH and of its contribution in the pathophysiology of inflammatory diseases (such as rheumatoid arthritis) characterized by high local expression of both these factors remains unclear.

\section{Acknowledgments}

The authors thank George Chrousos for the ACTH antibody, Lou Muglia for the $\mathrm{Crb}^{-1-} \mathrm{Il}^{-/-}$mice, and Fred Grant and Joseph Majzoub for their helpful suggestions during the preparation of this manuscript. This work was supported by the NIDDK grant RO1DK47977 (to K. Karalis).

1. Blalock, J.E. 1994. The syntax of immune-neuroendocrine communication. Immunol. Today. 15:504-511.

2. Blalock, J.E. 1994. Shared ligands and receptors as a molecular mechanism for communication between the immune and neuroendocrine systems. Ann. NY Acad. Sci. 741:292-298.

3. Bateman, A., Singh, A., Kral, T., and Solomon, S. 1989. The immunehypothalamic-pituitary-adrenal axis. Endocr. Rev. 10:92-112.

4. Fauci, A.S. 1978. Mechanisms of the immunosuppressive and antiinflammatory effects of glucocorticosteroids. J. Immunopharmacol. 1:1-25.

5. Karalis, K., et al. 1991. Autocrine or paracrine inflammatory actions of corticotropin-releasing hormone in vivo. Science. 254:421-423.

6. Stephanou, A., Jessop, D.S., Knight, R.A., and Lightman, S.L. 1990. Corticotrophin-releasing factor-like immunoreactivity and mRNA in human leukocytes. Brain Behav. Immun. 4:67-73.

7. Aird, F., Clevenger, C.V., Prystowsky, M.B., and Redei, E. 1993. Corticotropin-releasing factor mRNA in rat thymus and spleen. Proc. Natl. Acad. Sci. USA. 90:7104-7108.

8. Smith, E.M., Morrill, A.C., Meyer, W.J., and Blalock, J.E. 1986. Corticotropin releasing factor induction of leukocyte-derived immunoreactive ACTH and endorphins. Nature. 321:881-882.

9. Wilder, R.L. 1995. Neuroendocrine-immune system interactions and autoimmunity. Annu. Rev. Immunol. 13:307-338.

10. Horai, R., et al. 1998. Production of mice deficient in genes for interleukin (IL)-1alpha, IL- 1beta, IL-1alpha/beta, and IL-1 receptor antagonist shows that IL-1beta is crucial in turpentine-induced fever development and glucocorticoid secretion. J. Exp. Med. 187:1463-1475.

11. Barton, B.E. 1997. IL-6: insights into novel biological activities. Clin. Immunol. Immunopathol. 85:16-20.

12. Vallieres, L., and Rivest, S. 1999. Interleukin-6 is a needed proinflammatory cytokine in the prolonged neural activity and transcriptional activation of corticotropin-releasing factor during endotoxemia. Endocrinology. 140:3890-3903.

13. Bethin, K.E., Vogt, S.K., and Muglia, L.J. 2000. Interleukin-6 is an essential, corticotropin-releasing hormone-independent stimulator of the adrenal axis during immune system activation. Proc. Natl. Acad. Sci. USA. 97:9317-9322.

14. Naitoh, Y., et al. 1988. Interleukin-6 stimulates the secretion of adrenocorticotropic hormone in conscious, freely-moving rats. Biochem. Biophys. Res. Commun. 155:1459-1463.

15. Lyson, K., and McCann, S.M. 1991. The effect of interleukin- 6 on pituitary hormone release in vivo and in vitro. Neuroendocrinology. 54:262-266.

16. Lenczowski, M.J., Van Dam, A.M., Poole, S., Larrick, J.W., and Tilders, F.J. 1997. Role of circulating endotoxin and interleukin- 6 in the ACTH and corticosterone response to intraperitoneal LPS. Am. J. Physiol. 273:R1870-R1877.

17. Mastorakos, G., Chrousos, G.P., and Weber, J.S. 1993. Recombinant interleukin-6 activates the hypothalamic-pituitary-adrenal axis in humans. J. Clin. Endocrinol. Metab. 77:1690-1694. 
18. Tsigos, C., et al. 1997. Dose effects of recombinant human interleukin6 on pituitary hormone secretion and energy expenditure. Neuroen docrinology. 66:54-62.

19. Chrousos, G.P. 1995. The hypothalamic-pituitary-adrenal axis and immune-mediated inflammation. N. Engl. J. Med. 332:1351-1362.

20. Lymangrover, J.R., and Brodish, A. 1973. Tissue CRF: an extra-hypothalamic corticotrophin releasing factor (CRF) in the peripheral blood of stressed rats. Neuroendocrinology. 12:225-235.

21. Muglia, L., Jacobson, L., Dikkes, P., and Majzoub, J.A. 1995. Corticotropin-releasing hormone deficiency reveals major fetal but not adult glucocorticoid need. Nature. 373:427-432.

22. Jacobson, L., Muglia, L.J., Weninger, S.C., Pacak, K., and Majzoub, J.A 2000. CRH deficiency impairs but does not block pituitary-adrenal responses to diverse stressors. Neuroendocrinology. 71:79-87.

23. Karalis, K.P., Kontopoulos, E., Muglia, L.J., and Majzoub, J.A. 1999. Corticotropin-releasing hormone deficiency unmasks the proinflammatory effect of epinephrine. Proc. Natl. Acad. Sci. USA. 96:7093-7097.

24. Lymangrover, J.R., and Brodish, A. 1973. Physiological regulation of tissue-CRF. Neuroendocrinology. 13:234-245.

25. Turnbull, A.V., et al. 1994. Mechanisms of activation of the pituitary-adrenal axis by tissue injury in the rat. Psychoneuroendocrinology. 19:165-178.

26. Turnbull, A.V., and Rivier, C. 1996. Corticotropin-releasing factor, vasopressin, and prostaglandins mediate, and nitric oxide restrains, the hypothalamic-pituitary-adrenal response to acute local inflammation in the rat. Endocrinology. 137:455-463.

27. Kaibara, A., et al. 1998. Interleukin 6, but not ciliary neurotrophic factor or leukaemia inhibitory factor, is responsible for the acute phase response to turpentine-induced myositis. Cytokine. 10:452-456.

28. Kozak, W., et al. 1997. Sickness behavior in mice deficient in interleukin6 during turpentine abscess and influenza pneumonitis. Am. J. Physiol. 272:R621-R630

29. Turnbull, A.V., et al. 1999. CRF type I receptor-deficient mice exhibit a pronounced pituitary-adrenal response to local inflammation. Endocrinology. 140:1013-1017.

30. Grant, F.D., et al. 1993. Expression of the rat arginine vasopressin gene in transgenic mice. Mol. Endocrinol. 7:659-667.

31. Venihaki, M., Carrigan, A., Dikkes, P., and Majzoub, J.A. 2000. Circadian rise in maternal glucocorticoid prevents pulmonary dysplasia in fetal mice with adrenal insufficiency. Proc. Natl. Acad. Sci. USA. 97:7336-7341.

32. Song, D.K., et al. 1999. Differential involvement of central and peripheral norepinephrine in the central lipopolysaccharide-induced interleukin-6 responses in mice. J. Neurochem. 72:1625-1633.

33. Gatti, S., and Bartfai, T. 1993. Induction of tumor necrosis factor-alpha mRNA in the brain after peripheral endotoxin treatment: comparison with interleukin-1 family and interleukin-6. Brain Res. 624:291-294.
34. Muglia, L.J., et al. 1997. Impaired diurnal adrenal rhythmicity restored by constant infusion of corticotropin-releasing hormone in corticotropin-releasing hormone-deficient mice. J. Clin. Invest. 99:2923-2929.

35. Weninger, S.C., et al. 1999. Stress-induced behaviors require the corticotropin-releasing hormone (CRH) receptor, but not CRH. Proc. Natl. Acad. Sci. USA. 96:8283-8288.

36. Jeong, K.H., Jacobson, L., Widmaier, E.P., and Majzoub, J.A. 1999. Normal suppression of the reproductive axis following stress in corticotropin-releasing hormone-deficient mice. Endocrinology. 140:1702-1708

37. Fattori, E., et al. 1994. Defective inflammatory response in interleukin 6-deficient mice. J. Exp. Med. 180:1243-1250.

38. Bornstein, S.R., et al. 1998. Chronic effects of a nonpeptide corticotropin-releasing hormone type I receptor antagonist on pituitary-adrenal function, body weight, and metabolic regulation. Endocrinology. 139:1546-1555.

39. Makara, G.B., Stark, E., and Meszaros, T. 1971. Corticotrophin release induced by E. coli endotoxin after removal of the medial hypothalamus. Endocrinology. 88:412-414.

40. Stark, E., Makara, G.B., Marton, J., and Palkovits, M. 1973. ACTH release in rats after removal of the medial hypothalamus. Neuroendocrinology. 13:224-233.

41. Nakagawa, H., and Komorita, N. 1993. Complement component C3derived neutrophil chemotactic factors purified from exudate of rat carrageenin-induced inflammation. Biochem. Biophys. Res. Commun. 194:1181-1187.

42. Mantovani, G., et al. 1998. Cytokine activity in cancer-related anorex$\mathrm{ia} /$ cachexia: role of megestrol acetate and medroxyprogesterone acetate. Semin. Oncol. 25:45-52.

43. Scott, H.R., McMillan, D.C., Crilly, A., McArdle, C.S., and Milroy, R. 1996 The relationship between weight loss and interleukin 6 in non-small-cell lung cancer. Br.J. Cancer. 73:1560-1562.

44. Britton, D.R., Koob, G.F., Rivier, J., and Vale, W. 1982. Intraventricular corticotropin-releasing factor enhances behavioral effects of novelty. Life Sci. 31:363-367.

45. Morley, J.E., and Levine, A.S. 1982. Corticotrophin releasing factor, grooming and ingestive behavior. Life Sci. 31:1459-1464.

46. Krahn, D.D., Gosnell, B.A., Grace, M., and Levine, A.S. 1986. CRF antagonist partially reverses CRF- and stress-induced effects on feeding. Brain Res. Bull. 17:285-289.

47. Weninger, S.C., Muglia, L.J., Jacobson, L., and Majzoub, J.A. 1999. CRHdeficient mice have a normal anorectic response to chronic stress. Regul. Pept. 84:69-74.

48. Kalra, S.P., et al. 1999. Interacting appetite-regulating pathways in the hypothalamic regulation of body weight. Endocr. Rev. 20:68-100. 